\title{
ANALISIS FISIK, KIMIA DAN ORGANOLEPTIK MIE BASAH BERBASIS UMBI TALAS (Colocasia esculenta L)
}

\section{PHYSICAL, CHEMICAL AND ORGANOLEPTIC ANALYSIS OF WET NOODLE BASED ON TARO (Colocasia esculenta L)}

\author{
Ali Akbar \\ Program Studi Teknologi Pertanian Fakultas Pertanian, Universitas Dehasen Bengkulu \\ Email : aakbar86@gmail.com
}

\begin{abstract}
ABSTRAK
Mie basah adalah mie yang belum dimasak dengan kandungan air yang cukup tinggi hingga mencapai $52 \%$.Pengolahan mie basah dapat dilakukan dengan pencampuran tepung terigu dan tepung lainnya. Tepung talas telah digunakan dalam berbagai produk pangan diantaranya adalah makanan ASI (tambahan pendamping ASI), makanan kaleng untuk bayi, snack, mie, roti, dan biskuit. Hal ini dilakukan sebagai upaya diversifikasi pangan, pemanfaatan sumber pangan lokal serta peningkatan nilai gizi pangan. Telah dilakukan penelitian Untuk menganalisis pengaruh penambahan talas terhadap kandungan kadar air, elastisitas dan sifat organoleptik mie basah.

Metode dalam penelitian meliputi Pencampuran, Pembentukan lembaran mie dan pembaluran, Pencetakan mie, Perebusan 3 menit, suhu $90^{\circ} \mathrm{C}$, Penirisan dan Pembaluran. Perlakuan terhadap masing-masing sampel yaitu perbandingan Tepung terigu 450 gr : talas kukus 50 gr, Tepung terigu 400 gr : talas kukus 100 gr, Tepung terigu 350 gr : talas kukus $150 \mathrm{gr}$, Tepung terigu $450 \mathrm{gr}$ : tepung talas $50 \mathrm{gr}$, Tepung terigu $400 \mathrm{gr}$ : tepung talas $100 \mathrm{gr}$ dan Tepung terigu 350 gr : tepung talas 150 gr. Analisa pada penelitian ini meliputi kandungan kadar air, elastisitas dan sifat organoleptik mie basah.

Hasil analisa kandungan kadar air dengan perlakuan subtitusi tepung talas dan talas kukus berkisar antara $57.38 \%$ hingga $60.55 \%$, menunjukkan perbedaan yang nyata pada perlakuan. Hasil analisa elastisitas mie basah dengan perlakuan subtitusi tepung talas dan talas kukus berkisar antara 65.33 detik hingga 76.41 detik. Menunjukkan perbedaan yang nyata pada tiap perlakuan, dimana semakin tinggi subtitusi tepung talas dan talas kukus maka elastisitas mie semakin berkurang. Hasil uji sensoris mie basah berdasarkan parameter rasa menunjukkan perbedaan yang nyata pada setiap perlakuan dimana semakin tinggi subtitusi tepung talas dan talas kukus maka tingkat kesukaan panelis terhadap mie berkisar antara 2.55 hingga 2.95 (tidak suka), sedangkan penilai mie basah berdasarkan parameter warna dan tekstur menunjukkan perbedaan nyata pada setiap perlakuan dengan skor penilaian terhadap warna 2.45 (tidak suka) hingga 3.40 (agak suka) dan penilaian terhadap tekstur 2.30 (tidak suka) hingga 3.45 (agak suka).
\end{abstract}

Kata Kunci: Subtitusi, mie basah, umbi talas

\section{ABSTRACT}

Wet noodles are noodles that have not been cooked with high water content of up to 52 $\%$. Processing wet noodles can be made by mixing flour and other flour. Taro flour has 
been used in various food products which are fed with breast milk ( complementary addition) , canned food for babies, snacks, noodles, bread, and biscuits. This is done as a diversification effort, the use of local food sources as well as improving the nutritional value of food. Research has been conducted to analyze the effect of adding taro against moisture content, elasticity and organoleptic properties of a wet noodle .

Research methods include mixing, Formation sheets and pembaluran noodles, noodles Printing, Boiling 3 minutes, temperature $900 \mathrm{C}$, draining and Pembaluran. The treatment of each sample is $450 \mathrm{~g}$ flour ratio : taro steamed $50 \mathrm{~g}$, $400 \mathrm{~g}$ Wheat flour: steamed taro 100 grams, 350 grams of wheat flour: steamed taro $150 \mathrm{~g}, 450 \mathrm{~g}$ Wheat flour $: 50 \mathrm{~g}$ taro flour, wheat flour $400 \mathrm{~g}: 100 \mathrm{~g}$ taro flour and wheat flour $350 \mathrm{~g}: 150 \mathrm{~g}$ taro flour. The analysis in this study include the content of moisture, elasticity and organoleptic properties of a wet noodle.

The results of the analysis of moisture content with substitution treatment and taro steamed taro flour ranged from $57.38 \%$ to $60.55 \%$, showed significant differences in treatment. The results of the analysis with a wet noodle elasticity of substitution treatment and taro steamed taro flour ranged from 65.33 seconds to 76.41 seconds. Showed significant differences in each treatment, where the higher substitution and taro taro flour noodles steamed the elasticity decreases. The results of sensory test by a wet noodle taste parameters showed significant differences in any treatment where the higher substitution steamed taro taro flour and then the preference level of the noodles panelists ranged from 2:55 to 2.95 ( do not like ), while the wet noodle appraiser based on the color and texture parameters showed significant difference in each treatment with the assessment scores 2:45 color (do not like) until 3:40 ( rather like) and an assessment of the texture of 2:30 (did not like) until 3:45 ( rather like.

Keywords : Substitution, wet noodle, taro tuber

\section{PENDAHULUAN}

Umbi-umbian merupakan sumber karbohidrat yang mempunyai potensi untuk dikembangkan sebagai bahan pangan pengganti beras (bahan baku industri pangan maupun non pangan). Tanaman umbi-umbian umumnya ditanam di lahan semi kering sebagai tanaman sela. Produksi umbi-umbian di daerah sentra produksi pada saat panen raya sangat melimpah. Kadar air saat umbi-umbi dipanen biasanya mencapai $\pm 65 \%$. Kadar air yang tinggi ini menyebabkan umbi mudah rusak bila tidak segera dilakukan penanganan. Jika umbi segar telah di panen tidak segera diproses, maka akan terjadi perubahan visual yang ditandai dengan timbulnya bercak berwarna biru kehitaman, kecoklatan (browning), lunak (kepoyohan), umbi berjamur dan akhirnya menjadi busuk. Hal ini akan menyebabkan kehilangan hasil dan kemerosotan harga yang tajam pada saat panen raya didaerah sentra produksi (Suismono, 2001).

Tanaman talas (Coloccasia esculenta (L) Schott) adalah tanaman yang sudah lama dikenal di Indonesia. Tanaman talas menjadi makanan pokok bagi penduduk Indonesia bagian Timur seperti Irian (Tellawati, 1982). Umbi talas 
mempunyai kandungan karbohidrat yang cukup tinggi terutama pati yaitu sebesar 24,5\%. Oleh karena itu umbi talas berguna sebagai penghasil pati yang penting dan sebagai bahan baku industri (Bradbury, 1988). Lingga dan Sarwono (1992) menyatakn bahwa umbi talas dapat diolah menjadi getuk, keripik, roti, dan tepung talas. Tepung talas tergolong halus dan mudah dicerna berguna untuk pembuatan kue kering, kue basah, roti dan mie (Suhaeni, 2007).

Mie merupakan salah satu jenis makanan yang paling populer di Asia khususnya Asia Timur dan Asia Tenggara termasuk Indonesia. Mie tergolong sebagai produk pasta yaitu suatu produk bahan makanan dengan mencampurkan tepung terigu dan air serta berbagai bahan tambahan seperti garam, telur dan bahan tambahan lainnya (Sutomo, 2006). Secara umum mie dapat digolongkan menjadi dua yaitu mie kering dan mie basah mie kering seperti ramen, soba dan beragam mie instan. Sedangkan mie basah adalah mie yang belum dimasak dengan kandungan air yang cukup tinggi hingga mencapai $52 \%$ sehingga daya tahan simpannya relative singkat yakni 40 jam pada suhu kamar dan cepat basi. Pengolahan mie basah dapat dilakukan dengan pencampuran tepung terigu dan tepung lainnya (Ngantung, 2003 dan Sutomo, 2006).
Sejauh ini penelitian tentang pembuatan mie yang menggunakan subtitusi dari sumber tepung selaian terigu, yakni tepung talas dan talas kukus belum banyak dilakukan. Oleh karna itu perlu dilakukan penelitian tentang pengaruh subtitusi tepung talas dan talas kukus dalam pembuatan mie basah terhadap sifat fisik, kimia dan organoleptik mie basah. Sehingga penelitian ini dapat berguna untuk menambah peanekaragaman olahan tepung talas dan talas kukus sehingga dapat dijadikan peluang usaha baru dalam pembuatan mie basah

\section{METODE PENELITIAN}

\section{Bahan}

Bahan yang dibutuhkan dalam penelitian ini yaitu tepung talas, tepung terigu, tepung tapioka, baking powder, garam, telur air,dan minyak goreng

\begin{abstract}
Alat
Alat yang dibutuhkan dalam proses pengolahan mie basah yaitu pisau, sendok, tirisan, baskom, timbangan, wajan, cetakan mie dan kompor
\end{abstract}

\section{Pelaksanaan Penelitian}

Metode yang dilakukan dalam penelitian ini adalah sebagai berikut: 
1. Penelitian tahap awal dilakukan dengan membuat tepung talas sebagai berikut:

a. Persiapan Bahan Baku

Bahan baku pembuatan tepung talas yaitu umbi talas yang diperoleh dari Pasar Minggu Bengkulu

b. Sortasi dan Pencucian

Sortasi dilakukan untuk memilih talas yang tidak rusak, tidak busuk dan tidak terkena penyakit, selain itu dipil umbi talas dengan berat sekitar $0,5-1 \mathrm{~kg}$. Umbi talas kemudian dicuci untuk membersihkan semua kotoran dan tanah yang menempel pada kulit umbi.

c. Pengupasan dan Pengirisan

Talas dikupas kulitnya yang kemudian dicuci bersih, dengan air mengalir. Untuk menghilangkan kotoran yang menempel pada umbi dan tiriskan. Talas kemudian diiris-iris dengan ukuran 2-3 mm untuk memudahkan pengeringan.

d. Perendaman dalam air panas dan penirisan

Irisan talas direndam dalam air panas (1kg/2 liter air) dengan suhu $90^{\circ} \mathrm{C}$ selama dua menit. Setelah itu dilakukan penirisan selama 2 menit untuk mengeringkan sisa perendaman sehingga mempercepat pengeringan (Suastika, 1992) e. Penjemuran

Irisan talas kemudian dijemur di bawah sinar matahari langsung selama 24 jam dengan perhitungan 8 jam perhari yang ditandai dengan irisan talas mudah dipatahkan atau dihancurkan.

f. Penggilingan dan pengayakan

Setelah talas kering dilakukan penggilingan dengan mesin penggiling sampai halus. Setelah itu dilakukan pengayakan agar tepung yang dihasilkan lebih halus.

2. Pengolahan Talas Kukus

a. Sortasi

Sortasi dilakukan untuk memilih talas yang tidak rusak, tidak busuk dan tidak terkena penyakit.

b. Pencucian

Umbi talas dicuci untuk membuang kotoran dan sisa tanah yang terdapat pada kulit umbi talas.

c. Pengukusan

Talas dikukus selama 15 - 20 menit.

d. Pengupasan dan Penghalusan

Talas yang telah dikukus, dikupas dan dihaluskan.

3. Pengolahan Mie Basah

Pengolahan mie basah dengan perlakuan bahan baku terdiri dari talas kukus dan tepung talas dan perlakuan 
komposisi perbandingan tepung terigu dan talas. Proses pengolahan mie basah sebagai berikut:

a. Pembuatan adonan

Sesuai dengan perbandingan tepung terigu dan talas, kemudian ditambahkan dengan baking powder 5 $\mathrm{g}$, garam $10 \mathrm{~g}$, telur $100 \mathrm{~g}$, dan ditambah air $100 \mathrm{ml}$ kemudain diulen sehingga membentuk adonan yang kalis

b. Pembentukan lembaran mie dan pembaluran

Pembentukan lembaran mie menggunakan roll press. Kemudian dilakukan pembaluran dengan tepung terigu sebanyak 50 gr dengan tujuan agar mie yang dihasilkan dapat terpisah satu sama lainnya (Saptani, 2007)

c. Pencetakan mie

Pencetakan mie dengan menggunakan alat cetak mie

d. Perebusan

Perebusan dilakukan selama 3 menit dalam air panas dengan suhu $90^{\circ} \mathrm{C}$

e. Penirisan dan pembaluran

Setelah proses perebusan kemudian dilakukan penirisan dan pembaluran dengan minyak goreng $30 \mathrm{ml}$.

\section{Metode Penelitian}

Rancangan yang digunakan dalam penelitian ini yaitu Rancangan Acak
Lengkap (RAL) dengan faktor tunggal yaitu perbandingan tepung terigu dan talas dengan perlakuan sebagai berikut:
A1 = Tepung terigu $450 \mathrm{gr}$
A2 = Tepung terigu $400 \mathrm{gr}$
A3 = Tepung terigu $350 \mathrm{gr}$
$\mathrm{B} 1=$ Talas kukus $50 \mathrm{gr}$
B1 = Talas kukus $100 \mathrm{gr}$
B2 = Talas kukus 150 gr
$\mathrm{C} 1=$ Tepung talas $50 \mathrm{gr}$
$\mathrm{C} 2=$ Tepun talas $100 \mathrm{gr}$
$\mathrm{C} 3=$ Tepung talas $150 \mathrm{gr}$

\section{Analisa Penelitian}

Analisa penelitian yaitu dengan menganalisa kadar air dan elastisitas mie basah yang dihasilkan serta dilakukan uji organoleptik dengan parameter penilain terhadap warna, rasa dan tekstur dengan menggunakan panelis agak terlatih sebanyak 20 panelis.

\section{HASIL DAN PEMBAHASAN}

\section{Kadar Air Mie}

Air merupakan komponen penting dalam bahan makanan, karena dapat mempengaruhi penampakan, tekstur, serta cita rasa makanan. Kandungan air dalam makanan ikut menentukan acceptability, kesegaran dan daya tahan bahan (Winarno, 1995). Walaupun air bukan merupakan sumber nutrien, tetapi sangat esensial dalam proses biokimiawi organisme hidup. Oleh karena itu, kadar 
air dalam bahan pangan sangat menentukan sifat fisik, kimia, organoleptik dan umur simpan bahan pangan yang bersangkutan. Hasil analisa kadar air mie basah dengan perlakuan substitusi umbi talas dan tepung umbi talas dapat dilihat pada tabel 1.

Tabel 1 menjelaskan terdapat perbedaan yang nyata terhadap hasil analisa kandungan kadar air mie basah pada taraf signifikan 5\%. Diketahui bahwa hasil analisa kadar air dengan semakin banyak subtitusi tepung talas dan talas kukus menunjukkan kandungan kadar air yang lebih kecil, pada perlakuan subtitusi tepung talas 50 gr, 100 gr dan 150 gr menghasilkan kandungan kadar air sebesar $60,28 \%, 59,34 \%$ dan 57,38\% Kandungan kadar air pada setiap perlakuan dapat dipengaruhi oleh penambahn tepung talas pada pengolahan mie basah. Penurunan kadar air tersebut dapat disebabkan oleh berkurangnya penggunan tepung terigu, kadar air tepung terigu sebesar $12 \%$ (Direktorat Gizi Depkes RI, 1979). Sementara kandungan kadar air tepung talas sebesar 5,72\% (Hartati dan Prana, 2003) lebih rendah dibandingkan kadar air tepung terigu.

Perlakuan subtitusi talas kukus 50 gr, 100 gr, dan 150 gr menghasilkan kandungan kadar air sebesar $60.55 \%$, $60.15 \%$, dan $59.30 \%$. Kandungan kadar air pada mie basah dengan perlakuan subtitusi talas kukus lebih tinggi jika dibadingkan dengan mie basah pada perlakuan subtitusi tepung talas ini disebabkan oleh kandungan kadar air pada talas kukus lebing tinggi yaitu 69,2 \% (Direktorat gizi depkes RI, 1981). Perlakuan subtitusi tepung talas dan talas kukus sangat berpengaruh terhadap kandungan kadar air mie basah yang dihasilkan dimana semakin tinggi subtitusi tepung talas dan talas kukus maka kandungan kadar air mie lebih rendah.

\section{Elastisitas Mie Basah}

Kekenyalan mie basah dalam penelitian ini diketahui melalui akumulasi waktu yang dibutuhkan oleh mie untuk menahan beban 9,86 gram yang diberikan sampai mie tersebut putus, semakin lama waktu yang dibutuhkan mie untuk menahan beban sampai mie tersebut putus maka semakin elastis mie yang dihasilan. Hasil analisis terhadap waktu putus mie basah dengan perlakuan subtitusi tepung talas dan talas kukus dapat dilihat pada tabel 2. 
Tabel 1. Nilai Rata-rata Analisa Kadar Air Mie Basah

\begin{tabular}{|c|c|}
\hline Perbandingan & Kadar air $(\%)$ \\
\hline Terigu : Tepung Talas & $60.28 \mathrm{a}$ \\
$450: 50$ & $59.34 \mathrm{~b}$ \\
$400: 100$ & $57.38 \mathrm{c}$ \\
$350: 150$ & \\
\hline Terigu : Talas Kukus & $60.55 \mathrm{a}$ \\
$450: 50$ & $60.15 \mathrm{a}$ \\
$400: 100$ & $59.30 \mathrm{~b}$ \\
\hline
\end{tabular}

Ket :angka yang diikuti oleh kode huruf yang berbeda menunjukkan adanya perbedaan yang nyata pada taraf signifikansi $5 \%$.

Tabel 2. Nilai Rata-Rata Analisa Elastisitas Mie Basah

\begin{tabular}{|c|c|}
\hline Perbandingan & Elastisitas (detik) \\
\hline Terigu : Tepung Talas & $76.41 \mathrm{a}$ \\
$450: 50$ & $74.32 \mathrm{~b}$ \\
$400: 100$ & $68.62 \mathrm{~d}$ \\
$350: 150$ & \\
\hline Terigu : Talas Kukus & $71.26 \mathrm{c}$ \\
$450: 50$ & $67.16 \mathrm{e}$ \\
$400: 100$ & $65.33 \mathrm{f}$ \\
\hline
\end{tabular}

Ket :angka yang diikuti oleh kode huruf yang berbeda menunjukkan adanya perbedaan yang nyata pada taraf signifikansi $5 \%$.

Tabel 2. menjelaskan terdapat perbedaan yang nyata terhadap analisa elastisitas setiap perlakuan subtitusi tepung talas dan talas kukus pada pengolahan mie basah pada taraf $5 \%$. Pada perlakuan subtitusi tepung talas dan talas kukus semakin tinggi subtitusi tepung talas dan talas kukus maka waktu putus mie semakin cepat ditandai dengan waktu rata-rata putus mie yaitu perlakuan subtitusi tepung talas 50 gr, 100 gr dan 150 gr menunjukkan waktu putus 76,41 detik, 74,32 detik dan 68,63 detik. Sedangkan pada perlakuan subtitusi talas kukus 50 gr, 100 gr dan 150 gr 
menunjukkn waktu putus mie 71,26 detik, 67,16 detik dan 65,33 detik.

Elastisitas mie basah yang dihasilkan dengan perlakuan subtitusi tepung dan talas kukus dapat dipengaruhi oleh semakin kecilnya jumlah tepung terigu yang digunakan dalam pengolahan mie. Hal ini didukung oleh pendapat Anonim (2006) yang menyatakan bahwa subtitusi atau campuran tepung lain pada prodak mie yang semakin tinggi menyebabkan produk mie akan mudah putus karena kandungan gluten menurun. Tepung terigu banyak mengandung gluten atau protein terigu. Gluten terdiri dari protein gliadin dan glutenin. Gliadin berfungsi sebagai perekat dan menjadikan adonan lebih elastis sedangkan glutenin berfungsi menjadikan adonan tetap kokoh dan menahan gas $\mathrm{CO}_{2}$ sehingga adonan dapat mengembang serta terbentuk poripori (Anonim, 2008). Berkurangnya jumlah tepung terigu yang digunakan mengakibatkan terjadinya penurunan elastisitas mie basah.

\section{Organoleptik Rasa Mie Basah}

Cita rasa merupakan suatu kesan yang diterima melalui saraf indera pengecapan, yaitu lidah. Sebagai hasil hadirnya senyawa-senyawa yang larut dalam air (Soekarto, 1985). Rerata kesukaan panelis terhadap rasa mie basah dengan perlakuan subtitusi tepung talas dan talas kukus berkisar antara 2.55 (tidak suka) hingga 2.95 (tidak suka). Hasil analisa rasa mie basah dapat dilihat pada tabel 3 .

Tabel 3 Nilai Rata-Rata Uji Sensoris Rasa Mie Basah

\begin{tabular}{|c|c|}
\hline Perbandingan & Nilai Rata-Rata Rasa \\
\hline Terigu : Tepung Talas & $2.95 \mathrm{a}$ \\
$450: 50$ & $2.80 \mathrm{a}$ \\
$400: 100$ & $2.70 \mathrm{a}$ \\
$350: 150$ & \\
\hline Terigu : Talas Kukus & $2.75 \mathrm{a}$ \\
$450: 50$ & $2.65 \mathrm{~b}$ \\
$400: 100$ & $2.55 \mathrm{~b}$ \\
\hline
\end{tabular}

Ket : angka yang diikuti oleh kode huruf yang berbeda menunjukkan adanya perbedaan yang nyata pada taraf signifikansi $5 \%$. Ket Skala : 1= sangat tidak suka; 2 = tidak suka; $3=$ agak suka; $4=$ suka; $5=$ sangat suka 
Tabel 3 menjelaskan bahwa hasil uji sensoris terhadap rasa mie basah menunjukkan perbedaan yang nyata pada taraf 5\%, ditunjukkan dengan hasil rerata uji sensoris. Pada perlakuan subtitusi tepung talas 50 gr, 100 gr dan 150 gr menunjukkan nilai rerata kesukaan panelis berkisar antara 2.70 hingga 2.95 berada pada skala penilaian tidak suka. sedangkan perlakuan subtitusi talas kukus pada pengolahan mie basah 50 gr, 100 gr dan 150 gr menunjukkan nilai rerata kesukaan panelis berkisar antara 2.55 hingga 2.75 berada pada skala penilaian tidak suka.

Hasil uji sensoris terhadap rasa mie basah dipengaruhi oleh semakin tingginya talas kukus yang digunakan dalam pengolahan mie basah, sehingga penggunaan tepung terigu berkurang dan mempengaruhi rasa mie basah. Perlakuan subtitusi tepung talas dan talas kukus mempengaruhi tingkat kesukaan panelis terhadap rasa mie basah yang semakin berkurang. Semakin tinggi subtitusi tepung talas dan talas kukus yang dugunakan maka rasa mie yang dihasilkan dominan rasa talas. Mie basah dengan rasa talas masih asing bagi panelis sehingga belum banyak disukai.

\section{Organoleptik Warna Mie Basah}

Rerata kesukaan panelis terhadap warna mie basah dengan perlakuan subtitusi tepung talas dan talas kukus berkisar antara 2.40 ( tidak suka) hingga 3.40 (agak suka). Hasil analisa warna mie basah dapat dilihat pada tabel 4 .

Tabel 4. Nilai Rata-Rata Uji Sensoris Warna Mie Basah

\begin{tabular}{|c|c|}
\hline Perbandingan & Nilai Rata-Rata Warna \\
\hline Terigu : Tepung Talas & $3.20 \mathrm{a}$ \\
$450: 50$ & $2.95 \mathrm{~b}$ \\
$400: 100$ & $2.45 \mathrm{c}$ \\
$350: 150$ & \\
\hline Terigu : Talas Kukus & $3.40 \mathrm{a}$ \\
$450: 50$ & $2.40 \mathrm{c}$ \\
$400: 100$ & $2.55 \mathrm{c}$ \\
\hline
\end{tabular}

Ket : angka yang diikuti oleh kode huruf yang berbeda menunjukkan adanya perbedaan yang nyata pada taraf signifikansi $5 \%$. Ket Skala : 1= sangat tidak suka; 2 = tidak suka; $3=$ agak suka; $4=$ suka; $5=$ sangat suka 
Tabel 4 menjelaskan bahwa hasil uji sensoris terhadap warna mie basah menunjukkan perbedaan yang nyata pada taraf signifikan 5\%, ditunjukkan dengan hasil rerata uji sensoris. Pada perlakuan subtitusi tepung talas $50 \mathrm{gr}, 100 \mathrm{gr}$ dan 150 gr menunjukkan nilai rerata kesukaan panelis berkisar antara 2.45 (tidak suka) hingga 3.20 (agak suka). Sedangkan perlakuan subtitusi talas kukus pada pengolahan mie basah 50 gr, 100 gr dan 150 gr menunjukkan nilai rerata kesukaan panelis berkisar antara 2.55 (tidak suka) hingga 3.40 (agak suka), dimana semakin besar subtitusi tepung talas dan talas kukus pada pengolahan mie basah maka tingkat kesukaan panelis terhadap warna mie basah semakin berkurang.

Hasil uji sensoris terhadap warna mie basah dipengaruhi oleh semakin besar jumlah tepung talas dan talas kukus yang pada pengolahan mie basah, serta kecilnya penggunan tepung terigu maka warna mie basah yang digunakan semakin coklat. Hal tersebut dapat disebabkan warna tepung talas lebih mengarah agak coklat, Warna coklat pada tepung talas diakibatkan adanya aktivitas enzim polyphenol oksidase (PPO). Enzim polyphenol oksidase dengan bantuan oksigen akan mengubah gugus monophenol menjadi O-hidroksi phenol, yang selanjutnya diubah menjadi Okuinon. Gugus O-kuinon inilah yang membentuk warna coklat (Anonim, 2007).

\section{Organoleptik Tekstur Mie Basah}

Rerata kesukaan panelis terhadap tekstur mie basah dengan perlakuan subtitusi tepung talas dan talas kukus berkisar antara 2.30 ( tidak suka) hingga 3.05 (agak suka). Hasil analisa tekstur mie basah dapat dilihat pada tabel 5 .

Tabel 5 menjelaskan bahwa hasil uji sensoris terhadap tekstur mie basah menunjukkan perbedaan yang nyata pada taraf signifikan 5\%, ditunjukkan dengan hasil rerata uji sensoris. Pada perlakuan subtitusi tepung talas 50 gr, 100 gr dan 150 gr menunjukkan nilai rerata kesukaan panelis berkisar antara 2.35 (tidak suka) hingga 3.05 (agak suka). Sedangkan perlakuan subtitusi talas kukus pada pengolahan mie basah 50 gr, 100 gr dan 150 gr menunjukkan nilai rerata kesukaan panelis berkisar antara 2.30 (tidak suka) hingga 3.45 (agak suka), dimana semakin besar subtitusi tepung talas dan talas kukus pada pengolahan mie basah maka tingkat kesukaan panelis terhadap tekstur mie basah semakin berkurang. 
Tabel 5 Nilai Rata-Rata Uji Sensoris Tekstur Mie Basah

\begin{tabular}{|c|c|}
\hline Perbandingan & Nilai Rata-Rata Tekstur \\
\hline Terigu : Tepung Talas & $3.05 \mathrm{~b}$ \\
$450: 50$ & $2.80 \mathrm{~b}$ \\
$400: 100$ & $2.35 \mathrm{c}$ \\
$350: 150$ & \\
\hline Terigu : Talas Kukus & $3.45 \mathrm{a}$ \\
$450: 100$ & $2.30 \mathrm{c}$ \\
$400: 100$ & $2.50 \mathrm{c}$ \\
\hline
\end{tabular}

Ket : angka yang diikuti oleh kode huruf yang berbeda menunjukkan adanya perbedaan yang nyata pada taraf signifikansi 5\%. Ket Skala : 1= sangat tidak suka; $2=$ tidak suka; $3=$ agak suka; $4=$ suka; $5=$ sangat suka

Hasil uji sensoris terhadap tekstur mie basah dipengaruhi oleh semakin besar jumlah tepung talas dan talas kukus yang pada pengolahan mie basah, serta kecilnya penggunan tepung terigu maka tekstur mie basah akan mudah patah. Hal ini didukung oleh pendapat Anonim (2006) yang menyatakan bahwa subtitusi atau campuran tepung lain pada prodak mie yang semakin tinggi menyebabkan produk mie akan mudah patah karena kandungan gluten menurun.

\section{KESIMPULAN}

Hasil analisa kandungan kadar air dengan perlakuan subtitusi tepung talas dan talas kukus berkisar antara 57.38\% hingga $60.55 \%$, menunjukkan perbedaan yang nyata pada perlakuan dengan dimana semakin tinggi subtitusi tepung talas dan talas kukus maka kandungan kadar air mie basah semakin rendah. Hasil analisa elastisitas mie basah dengan perlakuan subtitusi tepung talas dan talas kukus berkisar antara 65.33 detik hingga 76.41 detik. Menunjukkan perbedaan yang nyata pada tiap perlakuan, dimana semakin tinggi subtitusi tepung talas dan talas kukus maka elastisitas mie semakin berkurang dengan ditandai waktu putus mie semakin singkat. Hasil uji sensoris mie basah berdasarkan parameter rasa menunjukkan perbedaan yang nyata pada setiap perlakuan dimana semakin tinggi subtitusi tepung talas dan talas kukus maka tingkat kesukaan panelis terhadap mie berkisar antara 2.55 hingga 2.95 (tidak suka, sedangkan penilai mie basah berdasarkan parameter warna dan tekstur menunjukkan perbedaan nyata pada setiap 
perlakuan dengan skor penilaian terhadap warna 2.45 (tidak suka) hingga 3.40 (agak suka) dan penilaian terhadap tekstur 2.30 (tidak suka) hingga 3.45 (agak suka).

\section{DAFTAR PUSTAKA}

Astawan, M. 2005. Membuat Mie dan Bihun. Cet 7. Penebar Swadaya Jakarta.

Direktorat Gizi Departemen Kesehatan Republik Indonesia, 1979. Daftar Komposisi Bahan Makanan. Bhatara. Jakarta.

Hartati, N.S dan T.K. Prana 2003. Analisi Kadar Pati dan Serat Kasar Tepung Beberapa Kultivar Talas (Colocasia esculenta L.scott). Jurnal. Pusat Penelitain Bioteknologi LIPI. Cibinong. http://ww.jurnal-natur-indonesia .com. Diakses 16 Februari 2009

Kartika dkk. 1988. Pedoman Uji Inderawi Bahan Pangan. Universitas Gajah Mada. Jogjakarta

Lingga, P. L dan B. Sarwono. 1992. Bertanam Umbi-Umbian. PT. Penebara Swadaya. Jakarta

Lestari, B.W. 2008. Pengaruh Perbadingan Air Wortel dan Tepung Terigu Terhadap
Komponen Mutu Mie Basah. Skripsi. Fakultas Pertanian Universitas Mataram. Mataram

Pahrudin, 2005. Aplikasi bahan pengawet untuk memperpanjang umur simpan mie basah matang. Skripsi. Departemen Ilmu dan Teknologi Pangan. Fakultas Teknologi Pertanian. Institut Pertanian Bogor. Bogor

Soekarto, ST. 1985. Penilaian Organoleptik Untuk Industri Pangan dan Hasil Pertanian. Bharata Karya Aksara. Jakarta.

Saptani, M. 2007. Pengaruh Rasio Tepung Wortel (Daucus carota L) Terhadap Sifat Kimia dan Organileptik dalam Pembuatan Mie Basah. Skripsi. Fakultas Pertanian Universitas Mataram. Mataram

Tellawati, T. R. 1982. Mempelajari Pengaruh Varietas Talas Cara Sulfurisasi, dan Cara Pengeringan Pada Pembuatan Tepung Umbi Talas (Colocasia esaculenta (L) Schott). Thesis. Fakultas Pertanian IPB. Bogor

Winarno, F. G. Dan W. S. Rahayu. 1994. Bahan Tambahan untuk Pangan dan Kontaminan. Pustaka Sinar Harapan. Jakarta. 